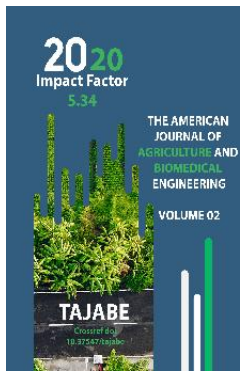

Journal Website: http://usajournalshub.c om/index,php/tajabe

Copyright: Original content from this work may be used under the terms of the creative commons attributes 4.0 licence.

\section{Measures For Control Of Drying Pests Of Citrus Crops}

\author{
Otabek Sulaymonov \\ Scientific Center For Plant Quarantine Of The State Plant Quarantine Inspection Under The \\ Cabinet Of Ministers Of The Republic Of Uzbekistan.
}

\section{Aziz Khakimov}

Scientific Center For Plant Quarantine Of The State Plant Quarantine Inspection Under The Cabinet Of Ministers Of The Republic Of Uzbekistan.

\section{Guzal Dusmurodova}

Scientific Center For Plant Quarantine Of The State Plant Quarantine Inspection Under The Cabinet Of Ministers Of The Republic Of Uzbekistan.

\title{
ABSTRACT
}

The article discusses the harm, biology and morphology of sucking pests of citrus crops. Citrus whitefly on citrus, in case of early settlement and high density, yield can be reduced up to $30 \%$. It can give up to 3-4 generations. In the conditions of the Bukhara and Khorezm regions of Uzbekistan, citrus whitefly (Dialeurodes citri.) Can develop, which is distinguished by its smaller size and yellowish color. Citrus aphids One of the most common and dangerous pests of lemons and tangerines is aphids. It most often affects the plant during the period of active growth of young shoots, settling on them and quickly sucking juice from them. By this, it slows down its development; one can also observe that the leaves of citrus dry and fall, and young growth dries out.

\section{KEYWORDS}

Harm, biology, morphology, generations, larva.

\section{INTRODUCTION}

Citrus whitefly it damages most deciduous trees such as lemon, mandarin, grapefruit, mountain ash, pear, apple, and some types of shrubs. As they develop, they feed on plant juices and contribute to the spread of black soot fungus. The leaves of plants, which they damage, deform, dry out and fall off. An adult individual secretes a special sticky substance that promotes the development of fungus on the leaves, which is why they turn yellow and die. 


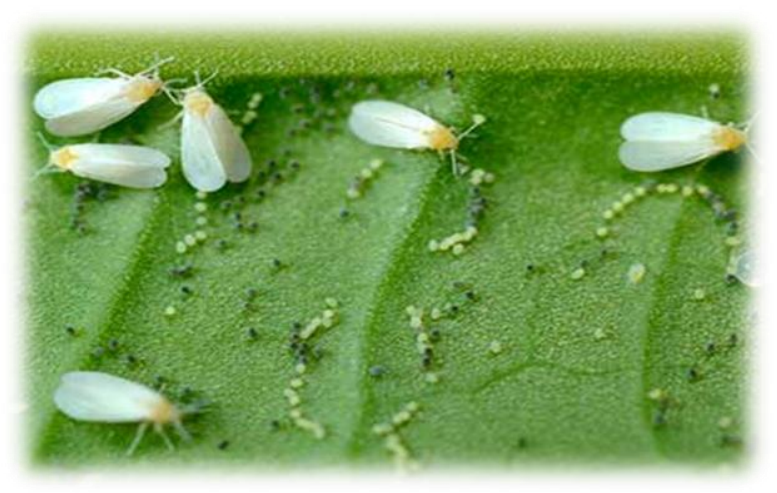

Figure: 1. Citrus whitefly

Aphids one of the most common and dangerous pests in lemons and tangerines is aphid. It most often affects the plant during the period of active growth of young shoots, settling on them and quickly sucking out the juice from them. By this, it slows down its development, you can also observe that citrus leaves dry up and fall, young shoots dry out.

\section{MATERIALS AND METHODS}

Whiteflies reproduce and spread in several stages. First of all, eggs are laid by the female (usually on the underside of the leaf). They have a small stalk that allows them to move around and look for a suitable place to feed. Having tightly attached to the surface of the plant, the larvae, within 5-10 days, develop and completely transform several times. At the final stage of its development, the larva changes the shape of the body and rebuilds, forming future legs, wings, antennae and other necessary organs of an adult. Fully hatched larvae resemble a gray crumb. They are also located on the lower surface of plant leaves. At this stage of their development, they are absolutely not susceptible to the damaging properties of insecticides. The adult whitefly is a tiny insect that resembles a small white moth with a yellowish belly. Its body length is only 1-2 $\mathrm{mm}$. Colonies of these

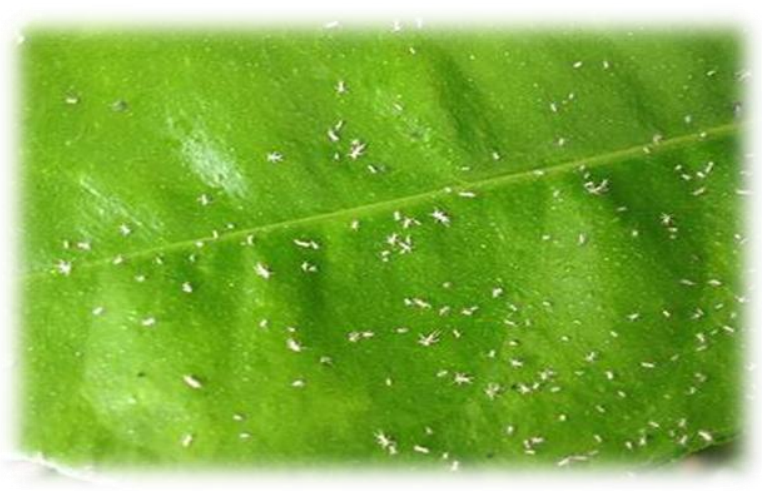

Figure: 2. Citrus aphid.

harmful insects affect both ornamental and garden plants, both in greenhouses and in the open field.

Aphid larvae are lighter, adults are darker. Because of this color, it is difficult to immediately notice it and take appropriate measures. This insect multiplies incredibly quickly, 15-25 generations can be born in less than a season. In the earliest stage of aphid infestation, this insect can be seen on the back of young leaves, on the ovary. If you saw at least one such representative on a lemon and you have a suspicion that aphids live on a lemon, there should be no questions about how to get rid of it, you should take action immediately. In the spring, the larvae appear first, they can be seen first. They settle in large groups mainly on young stem and leaves. This is due to the peculiarities of the structure, they feed by sucking the juice from the plants through the proboscis, in the larvae of aphids it is not strong enough, therefore it is much more convenient for them to use the young growth of citrus. The larvae are very voracious, as they need energy for growth and development. But if the situation is started, then adults will appear, which can lay a huge number of eggs in a short time. When there are a lot of aphids, individuals with wings 
begin to appear, which can migrate from plant to plant, lay eggs and increase the focus of infection.

\section{PURPOSE OF THE RESEARCH}

The data obtained during the tests on the effect of Mostar 20 pp. (LLC "AGROHOUSE", Uzbekistan) against whitefly on citrus are presented in the table. Whence it can be seen that the maximum effect was noted on day 3 and amounted to $86.2 \%$ and $87.3 \%$ after treatment with the drug at rates of 0.15-0.2 $\mathrm{kg} / \mathrm{ha}$. On days 7-14-21, the efficiency decreased sharply and amounted to $84.5 \%$ $82.7 \%, 77.4-80.0 \%-76.1-78.4 \%$. Maximum action of the standard Mospilan 20\% d.p. at a rate of $0.025 \mathrm{~kg} / \mathrm{ha}$, it was noted on day 3 and amounted to $82.4 \%$. On days $14-21$, the biological effectiveness is $76.3 \%-70.8 \%$ (table 1.).

Table 1.

Biological efficacy of Mostar 20 pp. against whitefly on citrus (farm "Sayid zhurakhon agro invest", Yukorchirchik district, Tashkent region, 20.06.2019)

\begin{tabular}{|c|c|c|c|c|c|c|c|c|c|c|c|}
\hline \multirow{3}{*}{ № } & \multirow{3}{*}{ Options } & \multirow{3}{*}{$\begin{array}{l}\text { Consumption } \\
\text { rates of } \\
\text { drugs, kg, } \\
\text { 1/ha }\end{array}$} & \multicolumn{5}{|c|}{$\begin{array}{l}\text { Average number of whitefly } \\
\text { per infected leaf, specimen }\end{array}$} & \multicolumn{4}{|c|}{$\begin{array}{c}\text { Biological } \\
\text { efficiency, } \%\end{array}$} \\
\hline & & & \multirow{2}{*}{\begin{tabular}{|c|} 
Before \\
processing
\end{tabular}} & \multicolumn{8}{|c|}{ After processing the other day } \\
\hline & & & & 3 & 7 & 14 & 21 & 3 & 7 & 14 & 21 \\
\hline 1 & Mostar 20 s.p & 0,15 & 14,7 & 2,9 & 3,7 & 5,3 & 6,4 & 86,2 & 82,7 & 77,4 & 76,1 \\
\hline 2 & Mostar 20 s.p & 0,2 & 16,0 & 2,9 & 3,6 & 5,1 & 6,3 & 87,3 & 84,5 & 80,0 & 78,4 \\
\hline 3 & $\begin{array}{l}\text { Mospilan } \\
20 \% \text { d.p. } \\
\text { (reference) }\end{array}$ & 0,025 & 14,3 & 3,6 & 4,6 & 5,4 & 7,6 & 82,4 & 77,9 & 76,3 & 70,8 \\
\hline 4 & \multicolumn{2}{|c|}{ Control (no processing) } & 16,6 & 23,8 & 24,2 & 26,5 & 30,3 & - & - & - & - \\
\hline
\end{tabular}

Coral from lemon juice (Aphididae) against larvae grown in greenhouse conditions, $10 \%$ e.k. - consumption 0.4 I / ha, Karat Gold 5\% em.k. consumption is $0.8 \mathrm{I} / \mathrm{ha}$ and Agroplan,
$20 \%$ x.k. The drug was used at a dose of $0.25 \mathrm{I} /$ ha. In the comparison variant, the consumption of Param 55\% em.k was 0.1 I / ha. Agroplan, 20\% x.k. When the drug was 
administered at a dose of $0.25 \mathrm{I} / \mathrm{ha}, 76.7 \%$ of the biological efficacy was obtained on the 7 th day after spraying compared to the comparison option, while on the 21st day the rate was $82.1 \%$. Karat Gold $5 \%$ em.k. In the variant applied to the drug at a dose of $0.8 \mathrm{~g} /$ ha, it was found that the biological efficiency reached $81.6 \%$ by the 7 th day and $90.2 \%$ by the 21st day. In the third option, i.e. Coral, $10 \%$ e.k.
- At a dose of $0.4 \mathrm{l} / \mathrm{ha}$, the effectiveness was $79.1 \%$ on the 7 th day after administration and $89.2 \%$ on the 21st day. Param in the comparison option is $55 \%$ em.k. when the drug was used at a rate of $0.1 \mathrm{I} / \mathrm{ha}$, the efficacy was slightly lower than in the experimental options, with $71.4 \%$ observed on the 7 th day and $76.4 \%$ on the 21 st day (table 2 .).

Table 2.

Biological efficacy of antifungal chemicals in citrus plants Tashkent region, Kibrap district, "Shomurod ogli LLC" f / x (Tashkent variety of lemon). working fluid - 600 I / ha, 2018

\begin{tabular}{|c|c|c|c|c|c|c|c|c|}
\hline \multirow{2}{*}{ № } & \multirow{2}{*}{ Options } & \multirow{2}{*}{$\begin{array}{c}\text { Consumption } \\
\text { of the drug is } \\
\text { l/ha }\end{array}$} & \multirow{2}{*}{$\begin{array}{l}\text { The average } \\
\text { number of } \\
\text { pests per } 10 \\
\text { leaves, pcs }\end{array}$} & \multicolumn{5}{|c|}{ Biological efficiency, \% } \\
\hline & & & & 1 & 3 & 7 & 14 & 21 \\
\hline 1 & $\begin{array}{c}\text { Agrotktan, } \\
20 \% \\
\text { FIRST. }\end{array}$ & 0,25 & 96,3 & 47.6 & 68.5 & 76,7 & 78,1 & 82,1 \\
\hline 2 & $\begin{array}{c}\text { Karat } \\
\text { Gold 5\% } \\
\text { em.k. }\end{array}$ & 0,8 & 75,6 & 62,3 & 71,8 & 81,6 & 87.5 & 90,2 \\
\hline 3 & $\begin{array}{c}\text { Coral, } \\
10 \% \text { e.k. }\end{array}$ & 0.4 & 88,5 & 55,1 & 69,2 & 79,1 & 84,1 & 89,2 \\
\hline 4 & $\begin{array}{c}\text { Param, } \\
55 \% \text { em.k. } \\
\text { (default) }\end{array}$ & 0,1 & 84,6 & 57,8 & 62.2 & 71.4 & 78.3 & 76.4 \\
\hline 5 & Control & unprocessed) & 86,4 & & & & & \\
\hline
\end{tabular}




\section{RESULTS AND CONCLUSIONS}

Include Mostar 20 s.p. (OOO "AGROHOUSE"., Uzbekistan) in the "List" of drugs allowed to fight against whitefly at rates of consumption of the drug $0.15-0.2 \mathrm{~kg} / \mathrm{ha}$, and at a rate of consumption of working fluid $250-300 \mathrm{I} /$ ha by the method of continuous processing plants with a hand sprayer. Mostar 20 s.p. possesses good biological efficiency against whitefly at rates of $0.15-0.2 \mathrm{~kg} / \mathrm{ha}$, exceeding the reference variant Mospilan 20\% dp.

\section{REFERENCES}

1. Sulaymonov O.A., Khakimov A.A., Yakheev Zh.N. Citrus whitefly (Dialeurodes citri). / Collection of materials of the IV international scientific and practical conference, "Week of Science in Kruty - 2018", -Ukraine, -P. 165167.

2. Sulaymonov O.A., Murodov B.E., Yaxyoev J.N. Citrus white - Dialeurodes citri. // Plant protection and quarantine. Tashkent, 2016. -№3 (11). - P. 39-40

3. Sulaymonov O.A., Khakimov A.A., Yakheev Zh.N. Sucking pests of citrus crops and methods of control // Actual problems of modern science. - 2020. - No. 2 (111). - P. 176-178.

4. Sulaymonov O.A., Khakimov A.A., Dusmurodova G.T. Harm of sucking pests of citrus crops // EURASIAN UNION OF SCIENTISTS (ESU). - 2020. - P. 31-33.

5. Sulaymonov O.A., Khakimov A.A., Dusmurodova G.T. Harm of suiting citrus crops pest / Proceedings of International Multidisciplinary Scientific Conference on Innovative Technology Organized by Novateur Publications, India May 25th, 2020. P. 97-98.
6. Murodov B.E, Yakhoev Zh.N. Quarantine pests of internal quarantine of the Republic of Uzbekistan // Education and science in Russia and abroad. - 2017. - No. 3 (32). -FROM. 32-36. 